\section{Soviet's Freudian slip}

\section{Athens}

THE Soviet All-Union of Psychiatrists and Narcologists (AUSPN) is preparing a special session on Freudian theory, and has already begun publishing Freud's collected works, Soviet psychiatrists told a press conference at the World Psychiatric Conference this week. Speaking on "Psychiatry and Perestroika", the Soviet team pointed out that (as with so many changes in the Soviet Union today), the reappearance of Freud, and other innovators of psychological theory, was a return to the "Leninist" policies of the $1920 \mathrm{~s}$, after decades in which the whole concept of psychoanalysis and the unconscious was republished as "pseudo-science". Soviet psychology and psychiatry were, they stressed, originally founded on the German school of the early 1920 s, and the AUSPN now wanted to resume its contacts with Germans and other West European psychiatric associations.

"Perestroika," said Dr Alexsandr Karpov, of the USSR Ministry of Health, "like any great social event, has its effect on mental health too".

What the AUSPN was seeking, of course, was reinstatement in the World Psychiatric Association (WPA), from which (under its previous name of the AllUnion Society of Psychiatrists and Neuropathologists it resigned in 1983 to avoid expulsion over the issue of the political use of psychiatry. The key issue, therefore, was whether or not Soviet psychiatry had mended its ways, or could be seen to have done so while its former leaders, such as Dr Marat Vartanyan and Dr N. Zharikov still held high office in the AUSPN. (Both of these were present in Athens; neither was at the press conference.) The Soviet team stressed that things are changing in Soviet psychiatry, urging that it would be better to look at a more positive future than to the painful events of the past. But human rights campaigners were distributing a letter just received from Aleksandr Podrabinek, of the unofficial Independent Psychiatric Association in Moscow, listing a number of new admissions over the past few months, which, the letter said, were made on political grounds.

The Soviet team argued that perestroika is a slow process, that there are now stronger legal guarantees of patients' rights, the "psychiatric register" of former patients has been greatly reduced, and that earlier this year, a "verification team" of US psychiatrists and lawyers had been given wide facilities to visit Soviet psychiatric hospitals.

The Soviet team, was challenged by Dr Anatolic Koryagin - a former Soviet psychiatrist who was himself incarcerated for having revealed (in The Lancet) details of Soviet abuses - about the AUSPN's letter of withdrawal from the WPA in 1983. If they recognized that political abuse of psychiatry had taken place in the past, he asked, how did they evaluate the signatures of the current leaders of Soviet psychiatry on the letter of resignation, which accused the UK Royal College of Psychiatrists of conducting a "slanderous campaign against them".

The President of the Royal College added his own demand for a formal apolRESEARCH FUNDS

\section{MIT in the red}

\section{Boston}

IN what could be a portent of difficult financial times ahead, the Massachusetts Institute of Technology (MIT) has posted its first budget deficit in six years. A recent university report discloses a shortfall of more than \$5 million for the 1989 fiscal year, which ended in June. The deficit is largely a result of falling income at the Lincoln Laboratory, an MIT affiliate which is supported almost entirely by the Department of Defense (DoD).

This year's deficit could be early evidence of coming financial difficulties because of the university's substantial dependence on military funding. Kenneth A. Smith, vice president for research at the university, has predicted "significant cutbacks in military funds" for research by the 1991 fiscal year.

The deficit comes despite a small decrease in expenses from fiscal year 1988 which the university attributes to layoffs of subcontractors at Lincoln Laboratory. But operating revenues decreased faster. The resulting shortfall of more than $\$ 11$ million was reduced to $\$ 5$ million by consideration of nearly $\$ 6$ million in unrestricted gifts and other income.

More worrying for the university is that the deficit has arisen in spite of a 19.3 per cent increase in support from non-federal sources. Fiscal year 1989 marked the first time that industry and other private funds surpassed the National Science Foundation as the fourth largest sponsor of research. The top three remained the same: the Department of Energy, the Department of Health and Human Services, and the DoD.

Despite rising concern, there are few solid proposals for replacing lost income. But Kosta Tsipis, director of the Program in Science and Technology for International Security and long a critic of MIT's reliance on military research dollars, is to hold a "high-level" meeting of corporate, academic, government and military leaders later this year to explore the prospects for converting some of the militarysponsored work at the university to more constructive research. Seth Shulman ogy; particularly as the chief signatory to the 1983 letter, Dr Georgii Morozov was, in 1988 , elected an honorary president of the WPA - elected, it was stressed, by democratic, secret ballot and not imposed from above. The Soviet panel were reluctant to apologize on Georgii Morozov's behalf, but promised to inform him that an apology had been asked for. They would go no further than admitting that "mistakes were made in the past". But to the majority of press, psychiatrists and campaigners at the meeting, this answer was clearly insufficient.

Vera RIch

\section{GALILEO}

\section{Legal moves fail}

\section{Washington}

AFTER surviving an eleventh-hour legal attack, the launch of the space shuttle Atlantis, carrying the Jupiter probe Galileo, had to be postponed from 12 October because of a technical problem. But by Saturday all was well again, and the launch had been rescheduled for early this week - Tuesday, 17 October. The unexpected delay gave the anti-nuclear opponents of Galileo's flight a chance to appeal against the earlier legal ruling, but that too failed.

The delay, announced by the National Aeronautics and Space Administration (NASA) only an hour after it had been given legal permission to continue the countdown, was due to a malfunction in a computer controlling one of the main shuttle engines. Although the computer has a back-up, mission controllers decided to replace the offending part. This was successfully done on Saturday, allowing a new lift-off time at 12.57 p.m. on the following Tuesday.

A request for an injunction against the launch of Atlantis, on the grounds that the environmental hazards from accidental dispersion of the plutonium in Galileo's power generators had been improperly assessed (see Nature 341, 374; 1989), was turned down by Judge Oliver Gasch in the US District Court for the District of Columbia late last Tuesday.

Gasch declared that the court was not willing "to substitute its judgement ... for that of the government agency", a pronouncement that NASA took as a vindication of its risk assessment analysis but which Andrew Kimbrell, who argued for the injunction on behalf of the Foundation on Economic Trends, said was an abdication of the court's responsibility.

With legal recourse having failed, protesters may now attempt to make good their promise to prevent the launch by infiltrating the Kennedy Space Center and occupying the launch area. NASA has tightened security at the site, but is not publicly anticipating trouble.

David Lindley 